\title{
AN INVESTIGATION ON POSTGRADUATE DISSERTATIONS ADDRESSING THREE- DIMENSIONAL PERCEPTION IN SCOPE OF ART EDUCATION RESEARCH
}

\author{
Belgin BORAN ${ }^{1}$, Handan NARİN ${ }^{2}$, \\ Ömer ERDEM ${ }^{3}$
}

\begin{abstract}
ABSRACT
Research on art education has been being carried out since 1970s as an academic research field in our country. These studies include different kinds of subjects, methods, problems, and solutions of art education. However, it is observed that generally there is a tendency towards pictorial representations both in the course "Visual Arts" carried out in the primary and secondary education; and research related to the field. From this point of view, this study aims at investigating and objectivizing the proposition stated above over postgraduate dissertations. In this sense, the subjects and methods of the dissertations, written in the master and doctorate programs of higher education institutes which give art education, aimed at three-dimension perceptions in visual arts course in primary and secondary education were investigated. Another aim of this study is comparing the results obtained from the dissertations with the attainments directed to three dimensional works in the Guidebook of Ministry of Education, Visual Arts lesson. Accordingly, this is a descriptive study utilizing survey research method. The samples of the study are the full-text dissertations on the National Dissertation Center Database created by Higher Education Council (HEC). When the explored dissertations were examined, the results of the study showed that quite similar or close subjects were repeated, the problematic situation was revealed with applications tried and discovered less. In the case of methods, it was found that qualitative research method was widely used. When the subjects of the dissertations were compared with the attainments, it was concluded that neither sufficient research was conducted on three-dimensional perception and practice in dissertations nor these attainments found sufficient place among Ministry of Education's attainments.
\end{abstract}

Keywords: Art Education, Three Dimension, Postgraduate Dissertations

\footnotetext{
${ }^{1}$ Res. Asst., Cukurova University, Fine Arts Education , bboran(at)cu.edu.tr

${ }^{2}$ Res. Asst., Cukurova University, Fine Arts Education, hnarin(at)cu.edu.tr

${ }^{3}$ Res. Asst., Cukurova University, Art and Design Department, oerdem(at)cu.edu.tr
} 


\title{
SANAT EĞiTiMI ARAŞTIRMALARI KAPSAMINDA ÜÇ BOYUT ALGISINI ELE ALAN LISANSÜSTÜ TEZLERIN INNCELENMESI
}

\begin{abstract}
ÖZ
Ülkemizde sanat eğitimine yönelik araştırmalar 1970'li y1llardan bu yana akademik bir çalışma alanı olarak sürdürülmektedir. Bu araştırmalar sanat eğitiminin farklı konu, yöntem, sorun ve çözüm önerilerini içermektedir. Ancak, gerek ilk ve orta öğretim kurumlarında Görsel Sanatlar dersinin işlenişindeki, gerekse alana ilişkin araştırmalarında yaratıcılık algısının daha çok resimsel anlatımlara yöneldiği izlenmektedir. Buradan hareketle bu çalışma, yukarıda belirtilen yargıyı lisansüstü tezler üzerinden incelemeyi ve nesnelleştirmeyi amaçlamaktadır. $\mathrm{Bu}$ bağlamda sanat eğitimi veren yükseköğretim kurumlarının yüksek lisans ve doktora programlarında ilköğretim ve ortaöğretim görsel sanatlar dersi üç boyut algısına yönelik yapılmış tezlerin konu ve yöntemleri incelenmiştir. $\mathrm{Bu}$ tezler belirlenen anahtar kelimeler doğrultusunda yapılan araştırma sonucunda alanında toplam 3444 teze erişilmiştir. Taranan tezler içerisinde 14 tanesinin araştırılan konuya yönelik olduğu sonucuna ulaşılmıştır. Araştırmanın kapsamı doğrultusunda ulaşılan bu 14 tez konu ve yöntem bakımından incelenmiştir. Çalışmanın bir başka amacı da elde edilen verilerin Milli Eğitim Bakanlığı Görsel Sanatlar Eğitimi Kılavuzu'nda yer alan üç boyutlu çalışmalara yönelik kazanımların tezlerden elde edilen bulgularla karşılaştırılmasıdır. $\mathrm{Bu}$ doğrulta araştırmanın yöntemi tarama türünde betimsel bir araştırmadır. Araştırmanın örneklemini, Yüksek Öğretim Kurumu'nun oluşturduğu Ulusal Tez Veri tabanında yer alan ve tam metin olarak erişime açık olan tezler oluşturmaktadır.
\end{abstract}

Anahtar Kelimeler: Sanat eğitimi, üç boyut, lisansüstü tezler 


\section{INTRODUCTION}

In Turkey research on art education has started in 1970s and continued rapidly after universities' increase in number and their proliferation. However, it has been discussed in academic environments for a long time that the conducted research focus on limited subjects, the reviewed books are limited to certain books; and instead of finding solution suggestions to problems related to the field, the aim is describing the existing situation. For example, Özsoy (2001, p. 54) stated that when the research, dissertations, and articles related to art education are investigated; rather than examining field education, studies on practices or investigations on the other areas of the art are carried out. While identifying the problems of art education, suggestions for solutions should also be offered. Even solutions should be found, the found solution should be tried, the inadequate points should be determined and tried to be eliminated. Unless the problems are solved, the reflections of them are observed in each level from primary to higher education.

In addition to these discussions, the present study also aims to discover another problem from the point of assumption that art education research directed at generating three-dimensional perception is inadequate. Considering the research limitations, this study includes dissertations written in art education field between years 2004-2015. When all the dissertations related to art education are explored, a considerable amount of the studies creates the impression as if art education is a process realized only by the means of picture. Whereas, it is known that threedimensional studies contribute greatly to individual's physical, mental, and psychological development. Visual arts education is directly based on materials. In art work only pencil, paper, dye is not enough. Clay, wood, plaster, cartoon, fabric pieces etc. natural or artificial, all kinds of materials are used in these lessons now (Kırışoğlu, 2002, p.9). Especially the three-dimensional works contributing the development of several skills should be given wide coverage. Çapar noted the skills acquired through three-dimensional works as follow (Çapar, 2006, p.25):

Three-dimensional works, as they require directly forming with hand, improves children' abilities of using their hands. They strengthen children' grip of the form's or object's space and the relationship between the other forms and objects. Future's qualified architects, sculptors, and industrial designers takes the first step in the way of self-actualization by the means of three-dimensional works they encounter in their early ages. Furthermore, whatever profession they choose in the future, three-dimensional works give children the opportunity of getting ready for the life which is three-dimensional itself. They strengthen the grasp of space, depth, and volume. 
"Creative three-dimensional attempts strengthen the analytical thinking methods and decision-making ability" (Allen, 1978; p. 14-31; cited in Çapar, 2006). In addition, by the means of mentioned works children witness the evolution of the material while they are forming it with their hands and they comprehend that it is realized by themselves (Çapar, 2006, s. 26).

As a result, the dissertations directed to the subject of three-dimensional perception in art education have been included in this study. From this point of view, this particular study's purpose is, after exploring the dissertations on art education written between the years 2004-2015, to investigate whether there is a contribution of these dissertations on the attainments taking place in art education curriculum. With this aim, the selected dissertations have been investigated in terms of subject and method, then compared to attainments of visual arts course of Ministry of Education (ME).

\section{METHOD}

\subsection{Research Design}

This study is a descriptive, survey research. Survey research is a research model which describes a situation in the past or a situation which is still going on warts and all (Karasar, 2009, p. 77). In this context, the subjects and the methods of dissertations, written in the MA and $\mathrm{PhD}$ programs of higher education institutes providing art education, on three-dimensional perceptions in primary and secondary education visual arts lesson were examined. Moreover, the attainments in ME Visual Arts Education Guidebook aimed at three-dimensional works are compared with the findings obtained from the dissertations.

\subsection{Data Collection and Analysis}

In this study, The National Dissertation Center Database was used to collect data. After identifying 7 key concepts according to expert opinion related to Fine Arts Education, the research was conducted. These selected concepts were art education, visual arts, visual arts education, fine arts education, picture education, art teaching, and three-dimensional perception. After reviewing the database with these key words, 3444 dissertations were reached in total. In accordance with this study's purpose, the scope of the study is narrowed down and the dissertations on the theme of three-dimensional perception in art education at primary and secondary schools were identified, and then coded and listed in Excel. The dissertations which were not related to this study were excluded. During the coding process it was seen that many dissertations recurred in different reviews. By 
excluding these recurring dissertations from the coding list, each dissertation was included in the coding list only one time.

The reached dissertations on three-dimensional perception were codified according to their kinds (master of arts or doctorate), years they were written, and the university they belonged to. Thereafter, the dissertations were explored in terms of subject and method in depth. The obtained results were discussed by comparing how much the three-dimensional perception attainments take place among acquisitions in MA Visual Arts Guidebook and whether it is parallel with the results of this study's findings or not.

\section{RESULT AND DISCUSSION}

It has been found that out of 3444 dissertations reached after the review process, only 14 of them were about primary and secondary education visual arts lesson's three-dimensional perception attainments. The obtained results are displayed and discussed in tables below:

Table 1. Distribution of Postgraduate Dissertations Investigating Three-Dimensional Perception in Art Education According to Their Year, Kind, and University

\begin{tabular}{llll}
\hline Yll & Üniversite & Tür & Sayı \\
\hline 2004 & Gazi & PhD & 1 \\
& Uludağ ve Selçuk Uni. & MA & 2 \\
2005 & Marmara Uni. & MA & 1 \\
2006 & - & - & \\
2007 & - & - & \\
2008 & - & - & \\
2009 & Gazi & PhD & 2 \\
& and Karadeniz Tech. Uni. & MA & 2 \\
2010 & Selçuk, Dokuz Eylül and Ondokuz Mayıs & MA & 3 \\
& Uni. & & \\
2011 & Başkent Uni. & MA & 1 \\
2012 & Ondokuz Mayıs Uni. & MA & 1 \\
2013 & - & & \\
2014 & - & & \\
2015 & Necmettin Erbakan (Selçuk) Uni. & MA & 1 \\
\hline
\end{tabular}

As it is seen in Table 1, when the years of the dissertations on art education is examined; it is observed that there is no research conducted between the years 2006-2008 and 2013-2014 aimed at three-dimensional perception in primary and 
secondary education. The results show that the most number of postgraduate research was realized in the year 2009. When the results are examined in terms of dissertation type, $\mathrm{PhD}$ and MA dissertations are equal in number, and in terms of institution basically conducted in Gazi University. As the cause of this situation, the fact that Gazi University is the oldest institution giving art education can be asserted.

Table 2. The Distribution of Postgraduate Dissertations Investigating Three-Dimensional Perception in Art Education According to Their Methods

\begin{tabular}{lll}
\hline \multirow{2}{*}{ Method } & \multicolumn{2}{l}{ MA/PhD } \\
\cline { 2 - 3 } Qualitative & $\mathbf{f}$ & $\mathbf{\%}$ \\
Quantitative & 6 & 42,8 \\
Qualitative and Quantitative (mix) & 4 & 28,5 \\
Research Design & 4 & 28,5 \\
Experimental Research & $\mathbf{f}$ & $\mathbf{\%}$ \\
Survey Research & 5 & 35,7 \\
Case Study & 4 & 28,5 \\
Action Research & 4 & 28,5 \\
\hline
\end{tabular}

As it is seen in Table 2, when the distribution of methods used in related dissertations are examined, it is seen that the most frequently used research method is qualitative research; research model is experimental research respectively. It is natural that qualitative paradigm is used more frequently since the art education itself consists of authentic applications and works. However, experimental research design may often require quantitative analysis itself. Especially in art education research, neither qualitative nor quantitative research analysis may be adequate on their own.

Table 3. The Distribution of Postgraduate Dissertations Investigating Three-Dimensional Perception in Art in Education According to Their Data Collection Tools and Data Analysis Methods

\begin{tabular}{lll}
\hline \multirow{2}{*}{ Data Collection Method } & MA/PhD & \\
\cline { 2 - 3 } Interview & $\mathbf{f}$ & $\mathbf{\%}$ \\
Assessment Form & 7 & 50,0 \\
Questionnaire & 6 & 42,8 \\
Observation & 5 & 35,7 \\
& 5 & 35,7
\end{tabular}




\begin{tabular}{lll} 
Other & 3 & 21,4 \\
Document Review & 1 & 7,1 \\
Data Analysis & $\mathbf{f}$ & $\%$ \\
Descriptive Analysis & 8 & 57,1 \\
Statistical Analysis & 7 & 50,0 \\
Content Analysis & 1 & 7,1 \\
Document Analysis & 1 & 7,1 \\
\hline
\end{tabular}

As it is seen in Table 3, as data collection tool interview and the assessment form developed by the researchers are used most frequently. For the analysis of the data descriptive analysis is preferred by the researchers. Interview is the data collection tool which is frequently used in social sciences and it provides researcher with detailed information. As a result, it is understood that it is used in studies conducted in the field of art education.

Table 4. The Distribution of Postgraduate Dissertations Investigating Three-Dimensional Perception in Art in Education According to Their Subject Areas

\begin{tabular}{lc}
\hline Subject Area & MA/PhD \\
\hline Contribution/Impact on Creativeness & 4 \\
Three-Dimensional Thinking, Comprehension, Practice & 2 \\
Multi-Disciplinary Art Education Method & 1 \\
The Use of Art Critics Method & 1 \\
Productivity of Learning Environment and The Effect of Material & 1 \\
Variety & \\
Program Proposal for Ceramic Education & 1 \\
Illustration of Three-Dimensional Books & 1 \\
Teaching Method Research & 1 \\
Contribution to Self-Confidence Development & 1 \\
Study on the Sculptures in Museums & 1 \\
\hline
\end{tabular}

As it is seen in Table 4, it is found that the postgraduate dissertations focused on three-dimensional perception in art education are predominantly about investigating the contribution/impact of three-dimensional practices.

After these explorations, it is thought that to make sense of the mentioned dissertations; comparing the attainments for three-dimensional perception and practice in ME Visual Arts Teaching Program book with dissertations' purposes and problems is both important and necessary. The included attainments are shown in Table 5: 
Table 5. The Attainments Identified According to Three Learning Areas Stated in ME Visual Arts Lesson Teaching Program Booklet and The Attainments for Three-Dimensional Perception in The Identified Acquisitions

\begin{tabular}{|c|c|c|c|c|c|c|}
\hline $\begin{array}{l}\text { Primary } \\
\text { Education } \\
\text { Class } \\
\text { Level }\end{array}$ & $\begin{array}{l}\text { Formation } \\
\text { in Visual } \\
\text { Arts } \\
\text { f }\end{array}$ & $\%$ & $\begin{array}{l}\text { Visual } \\
\text { Arts } \\
\text { Culture } \\
\text { f }\end{array}$ & $\%$ & $\begin{array}{l}\text { Museum } \\
\text { Awareness } \\
\text { f }\end{array}$ & $\%$ \\
\hline 1. & 7 & - & 12 & & 5 & \\
\hline 2. & 8 & - & 9 & & 5 & \\
\hline 3. & $12+1$ & 7,6 & 7 & & 5 & \\
\hline 4. & $12+2$ & 14,2 & $5+2$ & 28,5 & 6 & \\
\hline 5. & $8+2$ & 20,0 & $5+2$ & 28,5 & 5 & \\
\hline 6. & $7+2$ & 22,2 & 9 & & $6+1$ & 14,2 \\
\hline 7. & 9 & - & 11 & & 10 & \\
\hline 8. & $6+1$ & 14,2 & $4+9$ & 69,2 & 8 & \\
\hline Total & $69+8$ & 10,3 & $62+13$ & 17,3 & $50+1$ & \\
\hline \multicolumn{7}{|l|}{$\begin{array}{l}\text { Secondary } \\
\text { Education } \\
\text { Class } \\
\text { Level }\end{array}$} \\
\hline 9. & 58 & & 21 & & & \\
\hline 10. & $17+7$ & 34,2 & 13 & & $6+1$ & 14,2 \\
\hline 11. & 23 & & 8 & & 5 & \\
\hline 12. & 34 & & 3 & & 5 & \\
\hline Total & $132+7$ & 5,0 & 45 & & $16+1$ & 5,8 \\
\hline
\end{tabular}

In Table 5, the attainments stated in ME's Visual Arts Teaching Program book has been examined; after the examination of activities and attainments and it has been detected that among the total 404 attainments in primary and secondary education, 30 of them $(7,5 \%)$ were found to be related to three-dimensional perception directly or indirectly. 


\section{To see the attainments in detail:}

Table 6. The Attainments Aimed at Three-Dimensional Perception in Ministry of Education's Visual Arts Lesson' Guidebook

3.Grade Can do original works based on the forms identified from the environment. (FVA)

4. Grade Indulges using lines in two and three-dimensional works. (FVA) Constructs with three-dimensional basic geometrical forms. (FVA) Differentiates between two and three-dimensional visual art works. (FVA)

Recognizes that three-dimensional works have different appearances from different perspectives. (VAC)

5. Grade Indulges creating original works with three-dimensional materials which give point and line effect.(FVA)

Expresses feelings, ideas, and impressions via various visual art techniques. (FVA)

Identifies which branch the work of art belongs to. (VAC)

Knows that the same topic can be conveyed through different technique, material and expression forms. (VAC)

6. Grade Uses point and line effect on three-dimensional works. (FVA)

Uses similarity, opposition, and repetition in two and threedimensional works.( FVA)

Discusses the contribution of creating various visual designs to their cultural accumulation based on the works of art in museums.(MA)

8. Grade Creates original compositions making use of artistic arrangement principles. (FVA)

Accepts that the art has its own way of expression. (VAC)

Recognizes that art's way of expression is universal. (VAC)

Obtains information about different art movements. (VAC)

Recognizes that different ways of expressions makes up branches of art. (VAC)

Knows that they can express their feelings and ideas through different branches of visual arts. (VAC)

Explains how the visual formation elements, in the work of art they see, are used according to artistic arrangement principles. (VAC)

Desires to learn the life stories of artists of universal and national works of art they encounter. (VAC)

Creates visual designs which reflect their feelings, ideas, and 


\begin{tabular}{ll}
\hline impressions. (VAC) \\
Makes judgment about the works of art they see. (VAC) \\
\hline 10.Grade & Shows interest in three-dimensional forms in nature and their \\
movements. (FVA) \\
Distinguishes the well-known sculptors and their works of art. \\
(FVA) \\
Explains the difference of sculpture from relief. (FVA \\
Recognizes Atatürk sculptures and monuments which hold artistic \\
value. (FVA) \\
Explains three-dimensional work techniques. (FVA) \\
Practices artistic arrangement principles in three-dimensional work \\
of arts. (FVA) \\
Does different forms of three-dimensional works. (FVA) \\
Creates three-dimensional designs based upon the works of art in \\
historical environments, museums, and art galleries. (MA)
\end{tabular}

*FVA: Formation in Visual Arts

*VAC: Visual Arts Culture

*MA: Museum Awareness

When Table 4 and Table 6 are compared; it has been found that in the learning domains of Ministry of Education's Visual Arts lessons, 7 dissertations directed to Formation in Visual Arts (FVA); 2 dissertations directed to Visual Arts Culture (VAC); 1 dissertation directed to FVA and VCA; and 1 dissertation directed to Museum Awareness (MA) and VAC were written. Two of the dissertations developed program proposals and one of the dissertations identified the student levels' in terms of three-dimensional perception. From the point of these results, it is concluded that the examined postgraduate dissertations mostly meet the attainments which are under the title of FVA as learning domain. In addition, it is observed that the attainments under the title of VAC are less in number. The fact that among the examined dissertations there is only one dissertation for each learning domain gives the implication that three-dimensional perception is perceived in one-way. As there is only one dissertation directed to MA among the learning domains, it can be inferred that museums are neglected in terms of three-dimensional perception improvement. It is seen that three-dimensional perception has not been addressed in a way including all three learning domains (cultural, formal, and museum) neither in postgraduate dissertations nor in primary and secondary education Visual Arts lesson. 


\section{CONCLUSION AND SUGGESTION}

It has been found that qualitative research method is the most frequently used research method according to the obtained results in terms of research methods used in dissertations. It is natural that qualitative paradigm is mostly used as art education field includes original practices and works in itself. Nevertheless, particularly in art education studies neither qualitative nor quantitative analysis can be sufficient.

It has been concluded after examining the dissertations that similar or quite close topics are repeated, the aimed problematic situations are revealed with lesspracticed and discovered applications. Art education is a field that requires a long process; as a result, it cannot be forced into only one trial or only one practice.

It is clearly seen when the dissertations are examined according to their subjects that research aimed at three-dimensional perception and practice is not given much place. Whereas, it is obvious that three-dimensional works both contribute to students' physical, mental, affective development; and improves a great number of skills such as sensing the object by touching (texture, stiffnesssoftness), grasping the object as reality, grasping the space of object in the environment, comprehending dimensional relations, understanding the relation of the object between location and space, the position of light and shadow on reality.

Nonetheless, it is observed that not only the examined dissertations neglected these points, but also they were not placed sufficiently among the attainments identified by Ministry of Education. Visual arts education is an educational process which aims improving students' two and three-dimensional perception. Only if this togetherness is paid attention, the visual arts education can result in successful outcomes. It should be taken into consideration that each child's opportunity to express themselves may vary; in addition, they should be supplied not only with two-dimensional expression opportunities, but also with three-dimension richness. Furthermore, students should also be provided with information on forms' aesthetic.

Depending upon these purposes; it is required that curriculums should be revised, in institutions giving art education the required opportunities and courses which are about form and three-dimensional formation should be introduced; institutional unwillingness towards three-dimensional works in primary and secondary education institutions, and physical inadequateness should be eliminated. 


\section{REFERENCES}

(Çapar, M. (2006). Temel eğitimde 9-12 yaş arası çocuklarda üç boyutlu çalışmaların yaratıcllı eğitimine etkisi. Doktora tezi, Gazi Üniversitesi, Ankara.

Karasar, N. (2009). Bilimsel Araştırma Yöntemleri. Ankara: Nobel Yayın Dağıtım Lt.Şti.

Kırışoğlu, T., O. (2002). Sanatta eğitim görmek öğrenmek yaratmak. (2.Bs.). Ankara: Pegem A Yayıncilik.

Özer, B., Yazar, T. \& Eren, A. (2013). 1992-2012 yılları arasında güzel sanatlar eğitimi alanında Türkiye'de yapılan lisansüstü tez çalışmalarının incelenmesi. Eğitimde Kuram ve Uygulama. Say1 9 (4): 497-510.

Özsoy, V. (2001). Güzel sanatlar (resim-iş) eğitiminde bilimsel araştırmalar. Eğitim ve Bilim. Cilt 26 (121), Temmuz: 51-57.

MEB (2006). Görsel sanatlar dersi ögretim programı (1-8. Sinıflar). Ankara.

MEB (2009). Ortaöğretim 9, 10, 11 ve 12. siniflar görsel sanatlar (resim) dersi öğretim programi. Ankara.Ankara 